\title{
PENGARUH LIKUIDITAS, PROFITABILITAS, DAN LEVERAGE TERHADAP ARUS KAS MASA MENDATANG PADA PERUSAHAAN PROPERTI DAN REAL ESTATE DI BEI
}

\author{
Desy Ayu Cahyanti ${ }^{1}$ \\ Pendidikan Akuntansi \\ Universitas PGRI Madiun \\ desy_uye@yahoo.co.id
}

\author{
Elva Nuraina ${ }^{2}$ \\ Pendidikan Akuntansi \\ Universitas PGRI Madiun
}

\section{Anggita Langgeng Wijaya ${ }^{3}$ \\ Akuntansi \\ Universitas PGRI Madiun}

\begin{abstract}
ABSTRAK
Penelitian ini bertujuan untuk mengetahui pengaruh likuiditas, profitabilitas, dan leverage baik secara simultan maupun parsial terhadap arus kas masa mendatang pada perusahaan properti dan real estate yang terdaftar di BEI periode 2010-2014. Teknik pengambilan sampel dengan menggunakan teknik purposive sampling sehingga diperoleh sampel sejumlah 34 perusahaan properti dan real estate periode 2010-2014. Teknik analisis data yang digunakan adalah regresi berganda. Hasil penelitian menunjukkan bahwa : (1) likuiditas dengan menggunakan proksi current ratio berpengaruh negatif terhadap arus kas masa mendatang, (2) profitabilitas dengan menggunakan proksi return on equity berpengaruh terhadap arus kas masa mendatang, (3) leverage dengan menggunakan proksi debt to equity ratio tidak berpengaruh terhadap arus kas masa mendatang, (4) likuiditas, profitabilitas, dan leverage secara simultan berpengaruh terhadap arus kas masa mendatang.
\end{abstract}

Kata Kunci : Likuiditas; Profitabilitas; Leverage; Arus kas masa mendatang

\begin{abstract}
This study aim is to determine the influence of liquidity, profitability, and leverage either simultaneously or partially to future cash flows on property and real estate companies listed on the IDX period 2010-2014. Sampling technique using purposive sampling technique so that obtained sample of 34 property and real estate companies period 2010-2014. Data analysis technique used is multiple regression. The result of the research shows that: (1) liquidity using current ratio proxy has negative effect on future cash flows, (2) profitability by using return on equity proxy has negative effect on the future cash flows, (3) leverage by using debt to equity ratio No effect on future cash flows, (4) liquidity, profitability, and leverage simultaneously affect the future cash flows.
\end{abstract}

Keywords : $\quad$ Liquidity; Profitability; Leverage; Future cash flows



ASSETS:

Jurnal Akuntansi dan Pendidikan Vol. 6 No. 1 Hlmn. 26-41 Madiun, April 2017 p-ISSN: 2302-6251 e-ISSN: 2477-4995

Artikel masuk: 5 April 2017 Tanggal diterima: 19 Maret 2017 


\section{PENDAHULUAN}

Laporan keuangan merupakan alat yang sangat penting untuk memperoleh informasi sehubungan dengan posisi keuangan dan hasil-hasil yang telah dicapai oleh perusahaan yang bersangkutan (Sunyoto, 2013: 60). Bagi setiap perusahaan laporan keuangan merupakan salah satu kewajiban perusahaan untuk menyajikan dan melaporkannya pada suatu periode akuntansi tertentu. Laporan keuangan sangat berguna dalam melihat kondisi suatu perusahaan, baik kondisi pada saat ini maupun dijadikan sebagai alat prediksi untuk kondisi di masa yang akan datang (Fahmi, 2014:34). SFAC No. 1 menyatakan tujuan dari laporan keuangan perusahaan yaitu menyediakan informasi yang bermanfaat bagi pembuatan keputusan bisnis dan ekonomis oleh investor yang ada dan yang potensial, kreditur, manajemen, pemerintah, dan pengguna lainnya (Fahmi, 2014: 34). Keputusan bisnis yang diambil oleh pengguna laporan keuangan digunakan untuk melihat kondisi keuangan saat ini dan digunakan pedoman untuk melakukan prediksi di masa yang akan datang melalui informasi keuangan yang dihasilkan oleh perusahaan.

Keputusan-keputusan ekonomi yang akan diambil oleh para pemakai laporan keuangan membutuhkan evaluasi terlebih dahulu atas kemampuan perusahaan dalam menghasilkan laba (kas dan setara kas) serta kepastian hasil tersebut. Melalui laporan keuangan, investor dapat menganalisis hasil kinerja manajemen dan melakukan prediksi perolehan laba di masa yang akan datang. Selain hal tersebut, para investor juga dapat mengestimasi arus kas yang akan datang dalam laporan keuangan. Selain itu menurut SFAC No. 1 tujuan kedua dari pelaporan keuangan yaitu memberikan informasi tentang prospek arus kas untuk membantu investor dan kreditor dalam menilai propek arus kas bersih perusahaan (Muchlis, 2011). Secara umum laporan keuangan ada 5 yaitu laporan laba rugi, laporan perubahan modal, neraca, laporan arus kas, dan catatan atas laporan keuangan. Salah satu jenis laporan keuangan yang terkait dengan prediksi arus kas di masa depan adalah laporan arus kas. Menurut Prastowo (2011: 33), arus kas merupakan jiwa (lifeblood) bagi setiap perusahaan dan fundamental bagi eksistensi sebuah perusahaan serta menunjukkan dapat tidaknya sebuah perusahaan membayar semua kewajibannya. Laporan arus kas dikatakan fundamental karena laporan arus kas merupakan alat ukur yang sangat penting bagi pengguna laporan keuangan seperti investor, kreditor untuk menilai kemampuan perusahaan dalam menjalankan kegiatan operasi perusahaan. Laporan arus kas merupakan laporan yang menunjukkan arus kas masuk dan arus kas keluar perusahaan. Arus kas masuk berupa pendapatan atau pinjaman dari pihak lain. Adapun arus kas keluar merupakan biaya-biaya yang telah dikeluarkan perusahaan (Martani, Veronica, Wardhani, Farahmita, dan Tanujaya, 2012: 145). Informasi tentang arus kas suatu perusahaan berguna bagi para pemakai laporan keuangan sebagai dasar untuk menilai kemampuan perusahaan dalam menghasilkan kas dan setara kas, serta menilai kebutuhan perusahaan untuk menggunakan arus kas tersebut.

PSAK No 2 Tahun 2009 menyatakan bahwa jumlah arus kas yang berasal dari aktivitas operasi merupakan indikator yang menentukan apakah operasinya perusahaan dapat menghasilkan arus kas yang cukup untuk melunasi pinjaman, memelihara kemampuan operasi perusahaan, membayar dividen, dan melakukan investasi baru tanpa mengandalkan sumber pendanaan dari luar. Informasi mengenai unsur tertentu arus kas historis bersama dengan informasi lain berguna dalam memprediksi arus kas operasi masa depan. Menurut Subramanyam dan Wild (2011:93) aktivitas operasi merupakan aktivitas perusahaan yang terkait dengan laba. Terdapat dua pelaporan arus kas dari aktivitas operasi yaitu metode tidak langsung dan metode langsung. Perusahaan dianjurkan untuk melaporkan arus kas dari aktivitas operasi 


\section{ASSEES JURNAL AKUNTANSI DAN PENDIDIKAN

dengan menggunakan metode langsung. Alasannya metode langsung tersebut menghasilkan informasi yang berguna dalam mengestimasi arus kas di masa depan yang tidak dapat dihasilkan dengan metode tidak langsung. Dengan metode langsung, informasi mengenai kelompok utama penerimaan dan pengeluaran kas bruto dapat diperoleh dari catatan akuntansi dan dengan menyesuaikan pendapatan, harga pokok penjualan dan pos-pos lain dalam laporan laba rugi dengan perubahan rekening lancar, pos bukan kas dan pos lain yang berkaitan dengan arus kas aktivitas investasi dan pendanaan (Prastowo, 2011: 38).

Informasi arus kas historis sering digunakan sebagai indikator dari jumlah, waktu, dan kepastian arus kas masa depan (PSAK No 2 para 4 tahun 2009). Laporan arus kas yang disusun dengan tujuan untuk memberikan informasi historis mengenai perubahan kas dan setara kas dari suatu perusahaan. Perubahan yang terjadi pada kas dan setara kas yang dihasilkan perusahaan sangat berpengaruh terhadap keputusan bisnis, hal ini terkait dengan kemampuan perusahaan mampu tidaknya dalam menjalankan kegiatan operasi perusahaan. PSAK No. 2 mensyaratkan bahwa laporan arus kas menyajikan arus kas selama periode akuntansi yang relevan, yang diklasifikasi menjadi tiga kategori: operasi, investasi, dan pendanaan (Juan dan Wahyuni, 2012: 171). Kondisi keuangan suatu perusahaan dapat dilihat dari besarnya arus kas operasi perusahaan. PSAK No. 2 para 12 tahun 2009 menyatakan bahwa jumlah arus kas yang berasal dari aktivitas operasi merupakan indikator yang menentukan apakah operasi perusahaan dapat menghasilkan arus kas yang cukup untuk melunasi pinjaman, memelihara kemampuan operasi perusahaan, membayar dividen, dan melakukan investasi baru tanpa mengandalkan sumber pendanaan dari luar.

Prediksi tentang arus kas operasi masa depan penting bagi berbagai pihak pengguna informasi keuangan, baik pihak manajemen perusahaan maupun investor dan kreditor. Hal ini dikatakan penting karena dalam memprediksi arus kas operasi masa mendatang informasi tentang arus kas suatu entitas berguna bagi para pengguna laporan keuangan sebagai dasar untuk menilai kemampuan entitas dalam menghasilkan kas dan setara kas serta menilai kebutuhan entitas untuk menggunakan arus kas tersebut Rispayanto (2013). Menurut Ketua Umum Dewan Pengurus Pusat Real Estate Indonesia (REI) Setyo Maharso dalam pembukaan pameran properti REI di Jakarta, Indonesia masih menjadi negara tujuan untuk investasi di bidang properti. Hal itu terlihat dari banyaknya investor di negara lain yang berminat menanamkan modalnya dalam bidang properti di Indonesia. Selain itu banyak kalangan pengamat properti meramalkan bahwa kurang dari sepuluh tahun ke depan, sektor properti di Indonesia akan turut berperan sebagai salah satu sumber kekuatan ekonomi dunia. Indonesia pada tahun 2021 digadang-gadang menjadi negara dengan nilai kontribusi industri properti terbesar ke tujuh di dunia, mengalahkan Korea Selatan, Kanada, dan Jepang (Schreiben, 2013).

Kasmir (2015: 110) menyatakan bahwa rasio likuiditas merupakan rasio yang menggambarkan kemampuan perusahaan memenuhi kewajiban (utang) jangka pendek. Rasio likuiditas mempunyai tujuan untuk melakukan uji kecukupan dana, solvency perusahaan, kemampuan perusahaan membayar kewajiban-kewajiban yang segera harus dipenuhi. Rasio likuiditas disebut juga rasio modal kerja (Sunyoto, 2013: 85). Dalam penelitian ini rasio yang digunakan adalah rasio lancar atau current ratio. Semakin besar current ratio menunjukkan semakin tinggi kemampuan perusahaan dalam memenuhi kewajiban jangka pendeknya. Nilai current ratio yang baik akan meningkatkan kepercayaan investor mengenai kemampuannya dalam membayar utang jangka pendeknya. Current ratio yang baik dan memuaskan perusahaan sebesar 
200\% artinya bahwa setiap utang lancar Rp 1 akan dijamin dengan aktiva lancar sebesar Rp 2,-. Jika current ratio suatu perusahaan hanya sebesar $90 \%$ maka setiap utang lancar sebesar Rp 1,- akan dijamin dengan aktiva lancar sebesar Rp 0,9 sehingga perusahaan disebut dalam keadaan ilikuid (Sunyoto, 2013:88).

Menurut Kasmir (2015:113) rasio profitabilitas merupakan rasio untuk menilai kemampuan perusahaan dalam mencari keuntungan. Rasio ini juga memberikan ukuran tingkat efektivitas manajemen suatu perusahaan. Hal ini ditunjukkan oleh laba yang dihasilkan dari penjualan dan pendapatan investasi. Intinya bahwa penggunaan rasio ini menunjukkan efisiensi perusahaan. Daya tarik bagi pemilik perusahaan yaitu pemegang saham dalam suatu perseroan adalah profitabilitas (Sunyoto, 2013:113). Pemilik juga tertarik pada pembagian laba yang menjadi haknya yaitu seberapa banyak yang diinvestasikan kembali dan seberapa banyak yang dibayarkan sebagai dividen kepada mereka. Dalam penelitian ini rasio yang digunakan adalah Return On Equity (ROE). Rasio ini menunjukkan efisiensi penggunaan modal sendiri. Makin tinggi rasio ini, makin baik. Artinya posisi perusahaan makin kuat, demikian pula sebaliknya.

Rasio solvabilitas atau rasio leverage, merupakan rasio yang digunakan untuk mengukur sejauh mana aktiva perusahaan dibiayai dengan utang. Artinya, berapa besar beban utang yang ditanggung perusahaan dibandingkan dengan aktivanya. Dalam arti luas dikatakan bahwa rasio solvabilitas digunakan untuk mengukur kemampuan perusahaan untuk membayar seluruh kewajibannya baik jangka pendek maupun jangka panjang apabila perusahaan dibubarkan atau dilikuidasi (Kasmir, 2015:112). Menurut Fahmi (2014:75) rasio leverage adalah mengukur seberapa besar perusahaan dibiayai dengan utang. Pengurus bank dan kreditur jangka pendek sangat berminat pada kemampuan perusahaan untuk membayar utang-utangnya dalam jangka pendek. Namun para kreditur jangka panjang atau pemegang saham selain berminat pada kondisi jangka pendek justru berminat pada kondisi jangka panjang karena posisi keuangan jangka pendek betapa pun baiknya tidaklah selalu paralel dengan posisi keuangan jangka panjang (Munawir, 1988 dalam Sunyoto, 2013:102). Dalam penelitian ini rasio yang digunakan untuk mengukur rasio solvabilitas adalah debt to equity ratio. Untuk mencari rasio ini dengan cara membandingkan antara seluruh utang, termasuk utang lancar dengan seluruh ekuitas. Rasio ini berguna untuk mengetahui jumlah dana yang disediakan peminjam (kreditor) dengan pemilik perusahaan. Dengan kata lain rasio ini untuk mengetahui setiap rupiah modal sendiri yang dijadikan untuk jaminan utang (Kasmir, 2015:112).

Menurut penelitian yang dilakukan oleh Tommy (2007) tentang konsetrasi kepemilikan saham, risiko perusahaan, likuiditas saham, arus kas, dan nilai perusahaan dimana hasil penelitian menunjukkan bahwa dalam likuiditas saham berpengaruh signifikan terhadap arus kas bebas perusahaan manufaktur yang go public di Indonesia. Hasil penelitian yang dilakukan oleh Ramon (2009) mengenai pengaruh kemampuan prediktif laba dan arus kas operasi dalam memprediksi arus kas operasi masa depan menunjukkan bahwa laba berpengaruh signifikan positif terhadap arus kas operasi masa depan. Menurut Yuwana dan Christiawan mengenai analisa kemampuan laba dan arus kas operasi dalam memprediksi arus kas operasi masa depan menunjukkan bahwa dapat disimpulkan variabel laba bersih secara parsial memliki kemampuan untuk memprediksi arus kas operasi masa depan. Penelitian yang dilakukan oleh Setyaningsih (2011) tentang pengaruh earning, leverage, operating cycle, capital intensity dan operating cash flow terhadap arus kas operasi masa depan perusahaan yang terdaftar di Bursa Efek Indonesia (BEI) 
menunjukkan hasil bahwa rasio leverage yang diukur dengan variabel debt to equity ratio terdapat pengaruh terhadap arus kas masa depan perusahaan.

\section{METODE PENELITIAN}

Model penelitian yang digunakan dalam penelitian ini adalah analisis regresi berganda. Menurut Gujarati dalam Ghozali (2011: 95) analisis regresi pada dasarnya adalah studi mengenai ketergantungan variabel dependen (terikat) dengan satu atau lebih variabel independen (variabel bebas/penjelas), dengan tujuan untuk mengestimasi dan /atau memprediksi rata-rata populasi atau nilai rata-rata variabel dependen berdasarkan nilai variabel independen.

Populasi dalam penelitian ini adalah perusahaan properti dan real estate yang terdaftar di Bursa Efek Indonesia. Berdasarkan data yang diperoleh peneliti, jumlah perusahaan properti dan real estate adalah 49 perusahaan yang datanya diperbarui pada 22 oktober 2015 di web saham OK. Sampel penelitian diambil dari populasi yang ada dengan menggunakan teknik purposive sampling yaitu teknik penentuan sampel dengan pertimbangan tertentu (Sugiyono, 2014: 126).

Jenis data yang digunakan yaitu data deret berkala (time series). Data deret berkala (time series) dikumpulkan selama kurun waktu tertentu. Dalam penelitian ini kurun waktu yang diteliti mulai tahun 2010 sampai dengan 2014. Data yang diteliti yaitu laporan keuangan yang sudah diaudit. Data yang dikumpulkan bersumber dari data sekunder yaitu data yang sudah diproses oleh pihak tertentu. Keseluruhan data dari perusahaan properti dan real estate yang go public yang diperlukan dalam penelitian diperoleh dari website resmi BEI yaitu wwww.idx.co.id.

Teknik analisis data dalam penelitian kuantitatif menggunakan teknik statistik dengan bantuan program IBM SPSS Statistics versi 22. Metode analisis data dalam penelitian ini menggunakan regresi linier berganda. Menurut Gujarati dalam Ghozali (2012: 95) analisis regresi pada dasarnya adalah studi mengenai ketergantungan variabel dependen (terikat) dengan satu atau lebih variabel independen (variabel bebas/penjelas), dengan tujuan untuk mengestimasi dan /atau memprediksi rata-rata populasi atau nilai rata-rata variabel dependen berdasarkan nilai variabel independen. Adapun rumus regresi linier berganda dalam penelitian ini adalah sebagai berikut :

$$
\mathrm{CFO}_{\mathrm{t}+1}=\alpha+\beta 1 \mathrm{CR}+\beta 2 \mathrm{ROE}+\beta 3 \mathrm{DER}+\epsilon
$$

Keterangan :

\begin{tabular}{|c|c|}
\hline $\mathrm{CFO} t+1$ & $=$ Cash Flow from Operation masa mendatang. \\
\hline a & $=$ Konstanta. \\
\hline$\beta 1 \ldots . . \beta 3$ & $=$ Koefisien regresi . \\
\hline CR & $=$ Current Ratio \\
\hline ROE & $=$ Return On Equity \\
\hline DER & $=$ Debt to Equity Ratio \\
\hline & $=$ Standar eror \\
\hline
\end{tabular}

Current ratio digunakan untuk mengukur kemampuan perusahaan membayar kewajiban jangka pendek atau utang yang segera jatuh tempo pada saat ditagih secara keseluruhan (Kasmir, 2015:110). Rumus current ratio (Sunyoto, 2013 : 88) adalah:

$$
\text { Current ratio }=\frac{\text { Aktiva lancar }}{\text { Utang lancar }}
$$


Return on equity digunakan untuk mengukur laba bersih sesudah pajak dengan modal sendiri. Rasio ini menunjukkan efisiensi penggunaan modal sendiri. Makin tinggi rasio maka makin baik (Kasmir, 2015:115). Rumus return on equity (Kasmir, 2015:137) adalah:

\section{Return on equity $=\underline{\text { Laba setelah bunga dan pajak }}$ Modal}

Debt to equity ratio digunakan untuk menilai utang dengan ekuitas. Untuk mencari rasio ini dengan membandingkan seluruh utang, termasuk utang lancar dengan seluruh ekuitas. Rasio ini berguna untuk mengetahui jumlah dana yang disediakan peminjaman (kreditor) untuk pemilik perusahaan (Kasmir,2015:112). Rumus debt to equity ratio (Kasmir, 2015:124) adalah:

\section{Debt to equity ratio $=\underline{\text { Total utang }}$ \\ Ekuitas}

Standar akuntansi keuangan per 1 Juli 2009 PSAK No. 2 para 12 tahun 2009, menyebutkan bahwa jumlah arus kas yang berasal dari aktivitas operasi merupakan indikator yang menetukan apakah operasi perusahaan dapat menghasilkan arus kas yang cukup untuk melunasi pinjaman, memelihara kemampuan operasi perusahaan, membayar dividen, dan melakukan investasi baru tanpa mengandalkan sumber pendanaan dari luar. Rasio CFO adalah:

$$
\text { Rasio } \mathrm{CFO}=\frac{\mathrm{CFO}_{\mathrm{t}+1}}{\text { Average Total Aktiva }}
$$

Sebelum dianalisis, variabel dalam penelitian ini harus dilakukan pengujian terlebih dahulu dengan menggunakan uji asumsi klasik. Tujuan uji asumsi klasik ini adalah untuk mengetahui pola dan varian serta kelinieritasan dari suatu populasi atau data (Siregar, 2014: 153). Uji asumsi klasik meliputi uji normalitas, uji multikolinieritas, uji heteroskedastisitas, dan uji autokorelasi.

Uji normalitas bertujuan untuk menguji apakah dalam model regresi, variabel penggangu atau residual mempunyai distribusi normal. Ada dua cara untuk mendeteksi apakah residual memiliki distribusi normal atau tidak yaitu analisis grafik dan analisis statistik (Ghozali, 2011:160). Analisis grafik yang digunakan dalam penelitian ini adalah dengan grafik histogram dan grafik P-P Plot. Pada grafik histogram, data yang mengikuti atau mendekati distribusi normal adalah distribusi data dengan bentuk lonceng (Ghozali, 2011:163). Jika nilai probabilitas atau sig. (2tailed) lebih besar dari 0.05 maka data tersebut terdistribusi normal, tetapi jika nilai probabilitas sig. (2-tailed) lebih kecil dari 0.05 maka distribusi data tersebut tidak normal (Ghozali, 2011:32).

Selanjutnya, model regresi yang baik seharusnya tidak terjadi korelasi di antara variabel independen. Jika variabel independen saling berkorelasi, maka variabelvariabel ini tidak ortogonal. Variabel ortogonal adalah variabel independen yang nilai korelasi antar sesama variabel independen sama dengan nol (Ghozali, 2011:105). Multikolonieritas dapat dilihat dari nilai tolerance dan VIF (Variance Inflation Factor). Kedua ukuran ini menunjukkan setiap variabel independen manakah yang dijelaskan oleh variabel independen lainnya. Tolerance mengukur variablitas variabel independen yang terpilih yang tidak dijelaskan oleh variabel independen lainnya. Jadi nilai tolerance yang rendah sama dengan nilai VIF tinggi (karena VIF=1/tolerance). 
Nilai Cutoff yang umum dipakai untuk menunjukkan adanya multikolonieritas adalah nilai tolerance $\leq 0.10$ atau sama dengan nilai $\mathrm{VIF} \geq 10$.

Uji autokorelasi bertujuan menguji apakah dalam model regresi linear ada korelasi antara kesalahan penganggu pada periode $t$ dengan kesalahan penganggu pada periode t-1 (sebelumnya) (Ghozali, 2011: 110). Model regresi yang baik adalah regresi yang bebas dari autokorelasi (Ghozali, 2011:110). Uji durbin-watson (DW) hanya digunakan untuk autokorelasi tingkat satu (first order autocorrelation) dan mensyaratkan adanya intercept (konstan) dalam model regresi dan tidak ada variabel lagi di antara variabel bebas (Ghozali, 2009:80). Kriteria uji autokorelasi adalah: (1) bila DW terletak antara batas atas atau upper bound (du) dan $4-\mathrm{du})$, maka koefisien autokorelasi sama dengan nol, berarti tidak ada autokorelasi, (2) bila nilai DW lebih rendah daripada batas bawah atau lower bound (dl), maka koefisien autokorelasi lebih besar daripada nol, berarti ada autokorelasi positif, (3) bila nilai DW lebih besar daripada (4 - dl), maka koefisien autokorelasi lebih kecil daripada nol, berarti tidak ada autokorelasi positif, (4) bila nilai DW terletak di antara batas atas (du) dan batas bawah (dl) atau DW terletak antara $(4-\mathrm{du})$ dan $(4-\mathrm{dl})$, maka hasilnya tidak dapat disimpukan.

Cara yang yang digunakan untuk mendeteksi ada tidaknya heteroskedastisitas dalam penelitian ini adalah dengan melihat diagram scatterplots . Pada scatterplot jika tidak ada pola yang jelas, serta titik-titik menyebar diatas dan dibawah angka 0 pada sumbu Y, maka tidak terjadi heteroskedastisitas (Ghozali, 2011:139).

Selanjutnya, dilakukan uji determinansi dengan melihat nilai R2. Nilai R2 yang kecil berarti kemampuan variabel-variabel independen menjelaskan variasi variabel dependen amat terbatas. Nilai yang mendekati satu berarti variabel-variabel independen memberikan hampir semua informasi yang dibutuhkan untuk memprediksi variasi variabel dependen (Ghozali, 2009:15).

Statistik F pada dasarnya menunjukkan apakah semua variabel independen yang dimasukkan dalam model mempunyai pengaruh secara bersama-sama atau simultan terhadap variabel dependen (Ghozali, 2009:16). Signifikasi model regresi pada penelitian ini diuji dengan melihat nilai signifikansi (sig.) dimana dikatakan berpengaruh apabila nilai sig $<0.05$.

Uji statistik $\mathrm{t}$ pada dasarnya menunjukkan seberapa jauh pengaruh satu variabel independen (current ratio, retuon on equity, dan debt to equity ratio) terhadap variabel dependen (future cash flow from operation) dengan menganggap variabel independen lainnya konstan (Ghozali, 2009:17). Signifikasi model regresi pada penelitian ini diuji dengan melihat nilai signifikansi (sig.) dimana dikatakan berpengaruh apabila nilai sig $<0.05$.

\section{HASIL PENELITIAN DAN PEMBAHASAN}

Uji normalitas bertujuan untuk menguji apakah dalam model regresi, variabel penggangu atau residual mempunyai distribusi normal. Ada dua cara untuk mendeteksi apakah residual memiliki distribusi normal atau tidak yaitu analisis grafik dan analisis statistik (Ghozali, 2011:160). Adapun hasil dari uji normalitas dengan uji Kolmogorov-Smirnov ada pada Lampiran 1. Sesuai dengan uji Kolmogorov-Smirnov yang ditunjukkan oleh tabel pada lampiran 1, nilai probabilitas atau Asymp. Sig. (2-tailed) sebesar 0,298. Oleh karena itu nilai probabilitas lebih besar dari 0,05 atau 0,298 >0,05 maka $\mathrm{H} 0$ diterima yang berarti data residual terdistribusi secara normal.

Uji multikolinieritas bertujuan untuk menguji apakah model regresi ditemukan adanya korelasi antar variabel bebas atau independen. Model regresi yang baik seharusnya tidak terjadi korelasi di antara variabel independen (Ghozali, 2011: 105). 
Hasil uji multikolinieritas dalam penelitian ini terdapat pada lampiran 2. Tabel pada lampiran 2 menunjukkan nilai VIF kurang dari 10 dan nilai tollerance lebih dari 0,1 untuk ketiga variabel independen, sehingga dapat disimpulkan bahwa model regresi dalam penelitian ini tidak terjadi masalah multikolinieritas.

Uji heteroskedastisitas bertujuan untuk menguji apakah dalam model regresi terjadi ketidaksamaan variance dari residual satu pengamatan ke pengamatan yang lain. Model regresi yang baik adalah yang homoskedastisitas atau tidak terjadi heteroskedastisitas (Ghozali, 2011:139). Hasil uji heteroskedastisitas dalam penelitian ini terdapat pada lampiran 3. Pada lampiran 3, grafik scatterplots terlihat titik-titik menyebar secara acak serta tersebar baik di atas maupun di bawah angka 0 pada sumbu Y. Hal ini dapat disimpulkan bahwa tidak terjadi heteroskedastisitas pada model regresi.

Uji autokorelasi bertujuan menguji apakah dalam model regresi linear ada korelasi antara kesalahan penganggu pada periode $t$ dengan kesalahan penganggu pada periode t-1 (sebelumnya) (Ghozali, 2011:110). Model regresi yang baik adalah regresi yang bebas dari autokorelasi (Ghozali, 2011:110). Adapun hasil uji autokorelasi pada penelitian ini ada pada Tabel 3 .

Nilai DW sebesar 1.616, jika dibandingkan dengan nilai tabel dengan menggunakan derajat kepercayaan 5\%, jumlah sample 55 dan jumlah variabel bebas 3 , maka diperoleh nilai du 1.6815. Nilai DW 1.616 kurang dari dari batas atas (du) yakni 1.6815 dan lebih besar dari batas bawah (dl) sebesar 1.4523 sehingga dapat disimpulkan bahwa tidak terdapat autokorelasi pada model regresi ini.

Setelah melakukan uji asumsi klasik, maka dapat diambil kesimpulan bahwa data layak untuk dianalisis menggunakan regresi linier berganda. Adapun hasil dari pengolahan regresi linier berganda adalah lampiran 5 Tabel 4. Hasil Regresi Linier Berganda. Berdasarkan lampiran 5 tabel 4, maka dapat dirumuskan persamaan regresi linier berganda dalam penelitian ini yaitu sebagai berikut:

$$
\text { CFO } t+1=0.071-0.015 C R+0.471 R O E-0.047 D E R+\epsilon
$$

Pengujian dugaan sementara dilakukan melalui uji signifikansi t dan F. Hasil uji signifikansi $\mathrm{t}$ dapat dilihat pada tabel 6 . Uji hipotesis pertama, berdasarkan dari hasil uji statistik $\mathrm{t}$ menunjukkan nilai $t_{\text {hitung }}$ sebesar -0.2076 dengan probabilitas signifikansi adalah 0.043. tingkat signifikansi tersebut adalah lebih besar dari taraf signifikansi $a=0.05$. Hal ini menunjukkan bahwa terdapat pengaruh antara likuiditas $(\mathrm{CR})$ dengan arus kas masa mendatang $\left(\mathrm{CFO}_{\mathrm{t}+1}\right)$. Variabel likuiditas $(\mathrm{CR})$ berpengaruh secara signifikan terhadap arus kas masa mendatang $\left(\mathrm{CFO}_{\mathrm{t}+1}\right)$. Setiap kenaikan maupun penurunan likuiditas berpengaruh terhadap arus kas masa mendatang. Akan tetapi dalam penelitian ini menunjukkan bahwa variabel likuiditas berpengaruh negatif terhadap arus kas masa mendatang. Hal ini menjelaskan bahwa setiap penurunan rasio likuiditas dengan proksi (CR) dapat meningkatkan arus kas masa mendatang $\left(\mathrm{CFO}_{t+1}\right)$. Hal ini disebabkan adanya peningkatan aktiva lancar selain kas, seperti : piutang, persediaan, dan aset keuangan lancar lainnya yang menyebabkan kas yang dimiliki perusahaan menurun. Kenaikan aktiva lancar selain kas membuat likuiditas perusahaan mengalami kenaikan dan kas perusahaan menurun yang membuat arus kas perusahaan mengalami penurunan. Kenaikan likuiditas dapat menurunkan arus kas masa mendatang. Hasil penelitian ini sejalan dengan penelitian yang dilakukan Tommy (2007) yang menyatakan bahwa likuiditas berpengaruh signifikan terhadap arus kas bebas perusahaan. Nilai current ratio yang baik bagi perusahaan akan dapat meningkatkan kepercayaan investor mengenai 


\section{ASSEES JURNAL AKUNTANSI DAN PENDIDIKAN

kemampuannya dalam membayar utang jangka pendeknya. Dengan kata lain, seberapa banyak aktiva lancar yang tersedia untuk menutupi kewajiban jangka pendek yang segera jatuh tempo.

Uji hipotesis kedua, berdasarkan nilai thitung sebesar 2.400 dengan tingkat signifikansi adalah 0.020. Tingkat signifikansi tersebut adalah lebih besar dari taraf signifikansi $a=0.05$. Hal ini menunjukkan bahwa terdapat pengaruh yang signifikan antara profitabilitas dengan indikator return on equity (ROE) terhadap arus kas masa mendatang $\left(\mathrm{CFO}_{t+1}\right)$. Variabel return on equity berpengaruh secara signifikan terhadap future cash flow from operation. Adapun nilai beta sebesar 0.471 sehingga return on equity mempunyai pengaruh positif terhadap future cash flow from operation. Artinya perolehan laba yang tinggi dapat meningkatkan arus kas masa mendatang. Ketika jumlah penjualan perusahaan naik dengan mengeluarkan biaya yang efisien maka dapat meningkatkan laba bersih perusahaan. Laba bersih yang dihasilkan oleh perusahaan akan meningkatkan kas dan setara kas yang dimiliki oleh perusahaan. Sehingga jika perusahaan memiliki laba bersih yang tinggi maka akan memiliki arus kas masa mendatang yang tinggi pula. Makin tinggi rasio ini, makin baik. Artinya posisi perusahaan makin kuat, demikian pula sebaliknya. Penelitian ini sesuai dengan penelitian yang dilakukan oleh Wanti (2012), dimana variabel laba bersih berpengaruh signifikan terhadap arus kas masa mendatang, disebabkan karena arus kas yang dihasilkan dari aktifitas operasi cukup untuk memelihara kemampuan operasi perusahaan, membayar dividen dan melakukan investasi baru, sehingga dimungkinkan penggunaan keuntungan perusahaan untuk menutupi arus kas masa mendatang. Hal ini juga didukung penelitian Putro (2007) yang mengemukakan bahwa laba mampu memprediksi arus kas operasi mendatang. Hal ini sesuai dengan penelitian yang yang dilakukan oleh Ramon (2013) bahwa laba memiliki pengaruh yang signifikan positif terhadap arus kas operasi masa depan. Semakin tinggi laba tahun berjalan maka arus kas operasi masa depan akan semakin naik. Hal ini sesuai dengan PSAK No. 2 yang menyatakan bahwa informasi arus kas sering digunakan sebagai indikator dari jumlah, waktu, dan kepastian arus kas masa depan.

Sedangkan uji hipotesis ketiga, nilai $t_{\text {hitung }}(-0.995)$ dengan tingkat signifikansi sebesar 0.324. Tingkat signifikansi tersebut adalah lebih besar dari taraf seignifikansi $a=0.05$. Hal ini menunjukkan bahw tidak terdapat pengaruh yang signifikan antara debt to equity ratio terhadap arus kas masa mendatang ( $\left.\mathrm{CFO}{ }_{t+1}\right)$. Variabel debt to equity ratio tidak berpengaruh signifikan terhadap arus kas masa mendatang. Artinya apabila leverage mengalami kenaikan maupun penurunan tidak mempengaruhi arus kas masa mendatang. Hal ini disebabkan karena dalam akun hutang perusahaan baik jangka pendek maupun jangka penjang terdapat akun hutang kepada pihak-pihak berelasi. Berarti dalam melakukan proses pinjaman perusahaan cenderung melakukan pinjaman kepada pihak-pihak berelasi. Pihak-pihak berelasi ini seperti, anggota keluarga dekat, entitas pemerintah yang merupakan pihak-pihak berelasi yang ikut serta dalam proses pengendalian dan pihak-pihak berelasi lainnya. Dimana melalui pinjaman kepada pihak-pihak berelasi perusahaan tidak dibebani dengan pembayaran bunga dan dalam proses pembayaran dapat dilakukan sewaktu-waktu sesuai permintaan dan kebutuhan kreditor. Sebagai bentuk kompensasi kepada pihak-pihak berelasi, perusahaan melakukan pembayaran melalui saham. Dalam hal ini ketika perusahaan mengalami penurunan kas dan setara kas, perusahaan dapat melunasi pinjamannya dengan menerbitkan saham baru. maka akan berdampak pada bertambahnya modal disetor dan juga saham beredar. Sehingga tingkat leverage perusahaan tidak mempengaruhi arus kas masa mendatang. Analisis leverage perusahaan berbeda dengan analisis likuiditas. Pada analisis likuiditas, jangka waktu 
biasanya pendek untuk peramalan arus kas yang lebih akurat. Peramalan jangka panjang kurang dapat diandalkan sehingga analisis leverage menggunakan ukuran analitis yang kurang akurat, tetapi lebih menyeluruh (Subramanyan dan Wild, 2011:262).

Berdasarkan lampiran 6 dapat dilihat tingkat signifikansi 0.014 yang lebih kecil dari $0.05(a=0.05)$. Maka dapat disimpulkan bahwa terdapat pengaruh silmultan yang signifikan antara Current Ratio (CR), Return On Equity (ROE), Debt to Equity Ratio (DER) terhadap Future Cash Flow from Operation ( $\mathrm{CFO}{ }_{\mathrm{t}+1}$ ). Berdasarkan hasil uji hipotesis dapat disimpulkan bahwa terdapat pengaruh antara likuiditas, profitabilitas dan leverage secara simultan yang signifikan terhadap arus kas masa mendatang. Dengan demikian $\mathrm{H}_{4}$ diterima. Informasi tentang arus kas suatu perusahaan berguna bagi para pemakai laporan keuangan sebagai dasar untuk menilai kemampuan perusahaan dalam menghasilkan kas dan setara kas, serta menilai kebutuhan perusahaan untuk menggunakan arus kas tersebut. Ada tiga rasio keuangan bagi investor yang paling dominan yang dijadikan rujukan untuk melihat kondisi kinerja suatu perusahaan yaitu: rasio likuiditas, rasio solvabilitas (rasio leverage), dan rasio profitabilitas (Fahmi, 2014: 58). Likuiditas penting karena kegagalan dalam membayar kewajiban jangka pendek dapat menyebabkan kebangkrutan suatu perusahaan. Jika tingkat likuiditas kuat maka suatu perusahaan mampu memenuhi tagihan jangka pendek, mampu memelihara modal kerja yang cukup untuk membelanjakan operasi perusahaan yang normal, mampu membayar bunga jangka pendek dan dividen, mampu memelihara credit rating yang mengungtungkan. Profitabilitas bermanfaat untuk menunjukkan keberhasilan perusahaan didalam menghasilkan keuntungan. Pengetahuan tentang keuntungan yang dihasilkan maka pemegang saham dapat mengetahui yang menjadi haknya yaitu seberapa banyak yang diinvestasikan kembali dan seberapa banyak yang dibayarkan sebagai dividen.

Leverage mengukur kemampuan perusahaan memenuhi kewajiban-kewajiban dalam jangka panjangnya. Karena para pengurus bank/kreditur selain berminat pada kemampuan perusahaan jangka pendek juga berminat pada kemampuan perusahaan dalam memenuhi utang jangka panjang. Konsep yang diterapkan investor adalah "think fast and decision fast" atau berpikir cepat dan mengambil keputusan secara cepat. Karena faktor itu maka investor menginginkan penggunaan rasio keuangan yang dianggap lebih fleksibel dan sederhana namun mampu memberi jawaban yang mereka inginkan (Fahmi, 2014:57). Ketiga rasio ini dikatakan representatif secara umum selalu menjadi perhatian investor karena secara dasar dianggap sudah merepresentasikan analisis awal tentang kondisi suatu perusahaan. Setelah diketahui kondisi suatu perusahaan maka dapat dilakukan prediksi untuk arus kas masa mendatang dengan proksi $\mathrm{CFO}_{t+1}$. Arus kas merupakan jiwa bagi setiap perusahaan dan fundamental bagi eksistensi sebuah perusahaan serta menunjukkan dapat tidaknya sebuah perusahaan membayar semua kewajibannya. Hal ini sesuai dengan PSAK No. 2 para 12 tahun 2009 menyatakan bahwa jumlah arus kas yang berasal dari aktivitas operasi merupakan indikator yang menentukan apakah operasi perusahaan dapat menghasilkan arus kas yang cukup untuk melunasi pinjaman, memelihara kemampuan operasi perusahaan, membayar dividen, dan melakukan investasi baru tanpa mengandalkan sumber pendanaan dari luar.

Koefisien determinasi $\left(\mathrm{R}^{2}\right)$ digunakan untuk mengetahui seberapa besar prosentase sumbangan pengaruh variabel independen secara serentak terhadap variabel dependen. Hasil uji koefisien determinasi dapat dilihat pada lampiran 7. Nilai Adjusted $R^{2}$ adalah sebesar 0.139 . Hal ini berarti bahwa sebesar $13,9 \%$ variabel dependen atau arus kas masa mendatang $(\mathrm{CFO}+1)$ dipengaruhi oleh variabel 


\section{ASSEES JURNAL AKUNTANSI DAN PENDIDIKAN

independen yaitu current ratio, return on equity, dan debt to equity ratio. sedangkan sisanya sebesar $86,1 \%$ variabel dependen dijelaskan oleh faktor-faktor lain diluar model regresi. Hasil uji koefisiens determinasi dapat dilihat pada lampiran 7.

\section{SIMPULAN}

Kesimpulan penelitian ini adalah pertama, variabel likuiditas berpengaruh negatif terhadap arus kas masa mendatang. Hal ini menunjukkan bahwa setiap penurunan rasio likuiditas dengan proksi $(\mathrm{CR})$ dapat meningkatkan arus kas masa mendatang $\left(\mathrm{CFO}_{\mathrm{t}+1}\right)$. Dimana setiap adanya peningkatan aktiva lancar selain kas, seperti : piutang, persediaan, dan aset keuangan lancar lainnya menyebabkan kas yang dimiliki perusahaan menurun. Pengaruh perputaran piutang terhadap profitabilitas. Kedua, variabel profitabilitas berpengaruh secara signifikan terhadap arus kas masa mendatang. Artinya perolehan laba yang tinggi dapat meningkatkan arus kas masa mendatang. Dimana ketika jumlah penjualan perusahaan naik dengan mengeluarkan biaya yang efisien maka dapat meningkatkan laba bersih perusahaan. Laba bersih yang dihasilkan oleh perusahaan akan meningkatkan kas dan setara kas yang dimiliki oleh perusahaan. Ketiga, variabel leverage tidak berpengaruh signifikan terhadap arus kas masa mendatang. Artinya apabila leverage mengalami kenaikan maupun penurunan tidak mempengaruhi arus kas masa mendatang. Hal ini disebabkan karena dalam melakukan proses pinjaman perusahaan cenderung melakukan pinjaman kepada pihak-pihak berelasi. Melalui pinjaman kepada pihakpihak berelasi perusahaan tidak dibebani dengan pembayaran bunga dan dalam proses pembayaran dapat dilakukan sewaktu-waktu. Variabel likuiditas dengan proksi current ratio (CR), profitabilitas dengan proksi return on equity (ROE), dan leverage dengan indikator debt to equity ratio (DER) berpengaruh secara simultan terhadap arus kas masa mendatang dengan indikator future cash flow from operation $\left(C F O{ }_{t+1}\right)$. Artinya dalam proses pengambilan keputusan terkait arus kas masa mendatang investor dapat menggunakan rasio keuangan likuiditas, leverage, dan profitabilitas.

Berdasarkan hasil simpulan dan keterbatasan, maka peneliti memberikan beberapa saran. Pertama, bagi perusahaan, hasil penelitian ini memperlihatkan bahwa likuiditas berpengaruh negatif terhadap arus kas masa mendatang. Perusahaan harus memperhatikan untuk melakukan pinjaman jangka pendek maupun jangka panjang dengan melihat dan menilai kemampuan kas perusahaan terlebih dahulu dalam membayar pinjaman, sehingga perusahaan tidak perlu mengeluarkan saham baru untuk melunasi pinjaman tersebut. Kedua, bagi investor, agar lebih mempertimbangkan likuiditas, profitabilitas, dan leverage dalam menilai arus kas masa mendatang perusahaan, sehingga investor dapat menilai kemampuan perusahaan dalam menghasilkan kas dan setara kas untuk kemudian melakukan prediksi terhadap arus kas masa mendatang. Ketiga, penelitian selanjutnya sebaiknya menggunakan variabel bebas lain seperti laba kotor, arus kas operasi, dan lain sebagainya. Penelitian ini hanya menggunakan likuiditas, profitabilitas, dan leverage sebagai variabel bebas dalam pengaruhnya terhadap arus kas masa mendatang. Penelitian yang menjadi sampel penelitian hanya dari perusahaan properti dan real estate yang berjumlah 34 perusahaan dengan tahun pengamatan pada periode tahun 2010 - 2014. Peneliti selanjutnya diharapkan menggunakan seluruh perusahaan dengan sampel yang lebih banyak dan tahun pengamatan yang lebih lama.

\section{DAFTAR PUSTAKA}

Ariani, M. D. (2010). Pengaruh Laba Kotor, Laba Operasi, dan Laba Bersih Dalam Memprediksi Arus Kas Di Masa Mendatang. Universitas Diponegoro. 
Andini, P. D. (2011). Kemampuan Prediksi Rasio-Rasio Keuangan Terhadap Laba dan Arus Kas Masa Depan dan Pengaruhnya Terhadap Dividend Payout Ratio Pada Perusahaan Manufaktur Jasa. Jurnal Akuntansi Universitas Jember 9 (2), 73-101.

Brigham, E. F. dan Houston, J. F. (2010). Dasar-Dasar Manajemen Keuangan Edisi 11 Buku 1. Jakarta: Salemba Empat.

Fahmi, I. (2014). Manajemen Keuangan Perusahaan Dan Pasar Modal. Jakarta: Mitra Wacana Media.

Ghozali, I. (2009). Ekonometrika(Teori, konsep, dan aplikasi dengan SPSS 17). Semarang: Badan Penerbit Universitas Diponegoro.

Ghozali, Imam. (2011). Aplikasi Analisis Multivariate Dengan Program IBM SPSS 19. Semarang: Badan Penerbit Universitas Diponegoro.

Gunawan, B., \& Mirantiningsih, A. (2007). Pengaruh Atribut Perusahaan Terhadap Relevansi Laba dan Arus Kas, Jurnal Akuntansi \& Investas, 8 (1), 72-91.

Ikatan Akuntansi Indonesia. (2014). Standar Akuntansi Keuangan Per Efektif 1 Januari 2015. Jakarta: Ikatan Akuntansi Indonesia.

Juan, Ng Eng \& Wahyuni, T. E. (2012). Panduan Praktis Standar Akuntansi Keuangan Edisi 2. Jakarta: Salemba Empat.

Kasmir. (2015). Pengantar Manajemen Keuangan Edisi Kedua. Jakarta: Prenadamedia Group.

Machdar, M. N., Diyani, A. L., \& Ahalik. (2013). Pengaruh Likuiditas dan Laba Terhadap Predikasi Arus Kas Masa Depan. Jurnal Mahasiswa Akuntansi 18 (2), 152-166.

Martani, D., Slyvia V., Ratna W., Aria F., \& Edward T. (2012). Akuntansi Keuangan Menengah Berbasis PSAK Buku 1. Jakarta: Salemba Empat.

Muchlis. (2011). Kemampuan Informasi Arus Kas, Gross Profit Margin dan Laba Dalam Memprediksi Arus Kas Masa Depan Pada Perusahaan Properti, Real Estate dan Consumer Goods Yang Terdaftar Di Bursa Efek Indonesia. Universitas Sumatera Utara Medan.

Pasadena, R. P. (2013). Pengaruh Likuiditas, Leverage, Profitabilitas, dan Ukuran perusahaan Terhadap Kebijakan Dividen Pada Perusahaan Manufaktur Yang Terdaftar di Bursa Efek Indonesia. Universitas Islam Negeri Jakarta.

Prastowo, D. (2011). Analisis Laporan Keuangan Konsep dan Aplikasi Edisi Ketiga. Yogyakarta: Unit Penerbit dan Percetakan AMP YKPN.

Putro, A. G. (2007). Analisis Kemampuan Laba dan Arus Kas Operasi Dalam Memprediksi Laba dan Arus Kas Operasi Mandatang. Universitas Sanata Dharma.

Ramon, T. K. (2009). Pengaruh Kemampuan Prediktif Laba dan Arus Kas Operasi Dalam Memprediksi Arus Kas Operasi Masa Depan (Studi Empiris Pada Perusahaan Property And Real Estat Yang Terdaftar DI BEI. Universitas Negeri Padang.

Reiys Schreiben. (2013). Propek Indonesia Menjadi Tujuan Utama Investasi Properti di Dunia. Diakses 25 Januari 2016, dari https://reiyslbs.wordpress.com/2013/05/08/prospek-indonesia-menjaditujuan-utama-investasi-properti-di-dunia/.

Rispayanto, S. (2013). Pengaruh Laba Kotor , Laba Operasi, Laba Bersih dan arus Kas Operasi Dalam Memprediksi Arus Kas Operasi Masa Mendatang. Skripsi diterbitkan. Universitas Negeri Padang.

Setyaningsih, R. (2011). Pengaruh Earning, Leverage, Operating Cycle, Capital Intensity, dan Operating Cash Flow Terhadap Arus Kas Operasi Masa Depan Perusahaan yang Terdaftar di BEI. Universitas Negeri Surakarta. 
Subramanyam, K. R. \& Wild, J. J. (2011). Analisis Laporan Keuangan Edisi 10 Buku 2. Jakarta: Salemba Empat.

Sugiyono. (2014). Metode Penelitian Kuantitatif, Kualitatif, dan Kombinasi (Mixed Methods). Bandung: Alfabeta.

Sunyoto, D. (2013). Analisis Laporan Keuangan Untuk Bisnis (Teori Dan Kasus). Yogyakarta: CAPS (Center Of Academic Publishing Service).

Tommy, P. (2007). Konsentrasi Kepemilikan Saham, Risiko Perusahaan, Likuiditas Saham, Arus Kas, dan Nilai Perusahaan, Jurnal Keuangan dan Perbankan, 14 (Edisi Khusus Oktober 2010), 641-651.

Wanti, F. K. P. (2012). Kemampuan Laba Bersih, Arus Kas Operasi dan Ratio Piutang Untuk Mempengaruhi Arus Kas Masa Mendatang Pada Perusahaan Food and Beverage di BEI. Jurnal Ilmiah Mahasiswa Akuntansi, 3, 36-41.

Yuwana, V., \& Chistiawan, Y. J. (2014). Analisa Kemampuan Laba dan Arus Kas Operasi Dalam Memprediksi Arus Kas Operasi Masa Depan. Business Accounting Review, 2 (1), 1-10. 


\section{LAMPIRAN}

Lampiran 1

Tabel 1. Hasil Uji Kolmogorov-Smirnov

\begin{tabular}{|l|l|r|}
\hline \multicolumn{2}{|c|}{ Model } & Unstandardized Residual \\
\hline $\mathrm{N}$ & & 55 \\
\hline Normal Parameter ${ }^{\mathrm{a}}$ & Mean & .0000000 \\
\hline & Std. Deviation & 1.12242754 \\
\hline Most Extreme & Absolut & .131 \\
\hline Differences & Positive & .085 \\
\hline & Negative &.-131 \\
\hline Kolmogorov-Smirnov Z & & .975 \\
\hline Asymp. Sig. (2-tailed) & & .298 \\
\hline
\end{tabular}

Lampiran 2

Tabel 2. Hasil Uji Multikolonieritas

\begin{tabular}{|l|r|r|c|}
\hline \multirow{2}{*}{ Model } & \multicolumn{2}{|c|}{ Collinearity Statistics } & \multirow{2}{*}{ Keterangan } \\
\cline { 2 - 3 } & Tolerance & VIF & \\
\hline 1. (Constant) & & & \\
\hline CR & .751 & 1.331 & $0.751>0,1 ; 1.331<10$ \\
\hline ROE & .861 & 1.162 & $0.861>0.1 ; 1.162<10$ \\
\hline DER & .689 & 1.451 & $0.689>0.1 ; 1.451<10$ \\
\hline
\end{tabular}

Lampiran 3

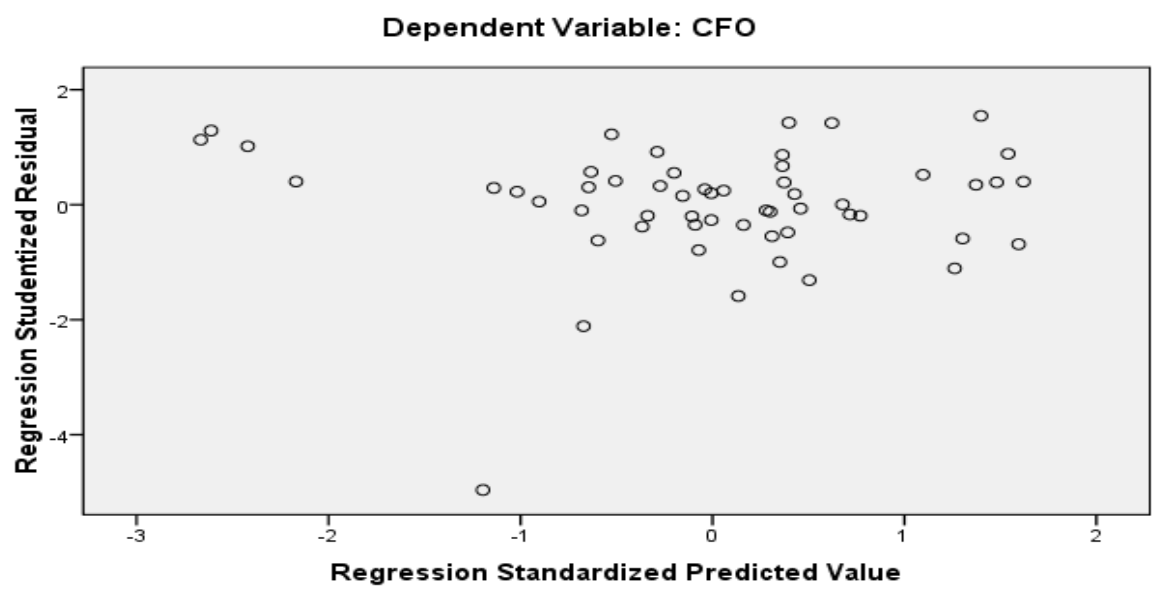

Gambar 1. Grafik Scatterplot untuk Uji Heteroskedastisitas

Lampiran 4

Tabel 3. Hasil Uji Autokorelasi

\begin{tabular}{|r|c|r|c|c|c|}
\hline \multirow{3}{*}{ Model } & \multirow{2}{*}{$\begin{array}{l}\text { Std. Eror of } \\
\text { the Estimate }\end{array}$} & \multirow{2}{*}{$\begin{array}{l}\text { Durbin- } \\
\text { Watson }\end{array}$} & \multicolumn{2}{|l|}{$\begin{array}{l}\text { Tabel } \\
\text { Watson Test Bound }\end{array}$} & \multirow{2}{*}{ Keterangan } \\
\cline { 4 - 5 } & & & $\mathrm{D}_{\mathrm{L}}$ & $\mathrm{D}_{\mathrm{U}}$ & \\
\hline 1 & .1443709510 & 1.616 & 1.4523 & 1.6815 & $1.4523 \leq 1.616 \leq 1.6815$ \\
\hline
\end{tabular}




\section{ASSEIS JURNAL AKUNTANSI DAN PENDIDIKAN

Lampiran 5

\begin{tabular}{|c|c|c|c|c|c|}
\hline \multirow[t]{2}{*}{ Model } & \multicolumn{2}{|c|}{$\begin{array}{c}\text { Unstandardized } \\
\text { Coefficients }\end{array}$} & \multirow{2}{*}{$\begin{array}{c}\begin{array}{c}\text { Standardized } \\
\text { Coefficients }\end{array} \\
\text { Beta }\end{array}$} & \multirow[t]{2}{*}{$\mathrm{T}$} & \multirow[t]{2}{*}{ Sig. } \\
\hline & B & Std. Error & & & \\
\hline 1. (constant) & .071 & .048 & & 1.487 & .143 \\
\hline CR & -.015 & .007 & -.302 & -.2076 & .043 \\
\hline ROE & .471 & .196 & .327 & 2.400 & .020 \\
\hline DER & -.047 & .047 & -.151 & -.995 & .324 \\
\hline
\end{tabular}

Lampiran 6

Tabel 5. Hasil Uji signifikansi F

\begin{tabular}{|l|r|r|r|r|c|}
\hline \multicolumn{1}{|c|}{ Model } & Sum of Squares & \multicolumn{1}{c|}{$\mathrm{f}$} & $\begin{array}{c}\text { Mean } \\
\text { Square }\end{array}$ & $\mathrm{F}$ & \multicolumn{1}{c|}{ Sig. } \\
\hline 1. Regression & .244 & 3 & .081 & 3.902 & $014^{\mathrm{a}}$ \\
\hline Residual & 1.063 & 1 & .021 & & \\
\hline Total & 1.307 & 4 & & & \\
\hline
\end{tabular}

Lampiran 7

Tabel 6. Hasil Uji Koefisien Determinasi

\begin{tabular}{|r|r|r|r|r|c|}
\hline Model & \multicolumn{1}{|c|}{$\mathrm{R}$} & R Square & $\begin{array}{c}\text { Adjusted R } \\
\text { Square }\end{array}$ & $\begin{array}{c}\text { Std. Eror of the } \\
\text { Estimate }\end{array}$ & $\begin{array}{c}\text { Durbin- } \\
\text { Watson }\end{array}$ \\
\hline 1 & .432 & .187 & .139 & .1443709510 & 1.616 \\
\hline
\end{tabular}

Lampiran 8

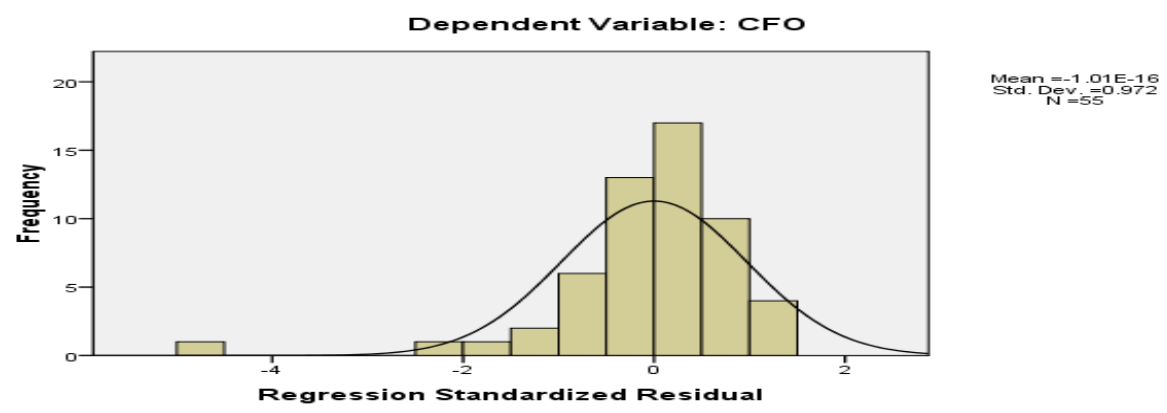

Gambar 2. Histogram Uji Normalitas

Normal P-P Plot of Regression Standardized Residual

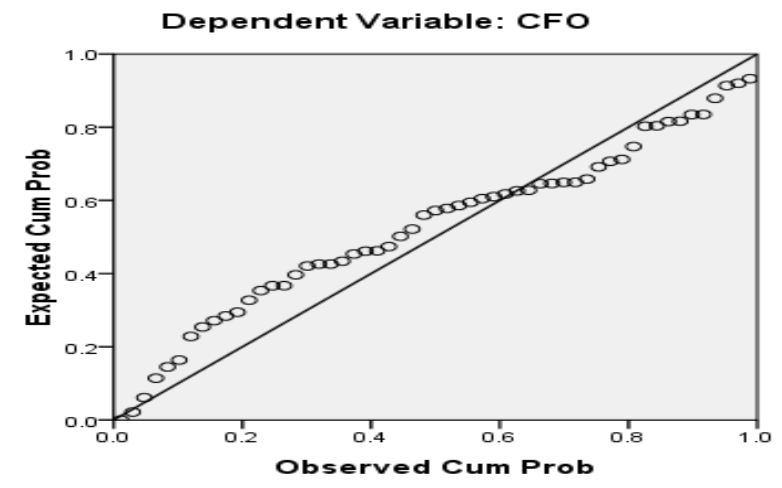

Gambar 3. Hasil Uji Normalitas 
CAHYANTI, D. A., NURAINA, E. \& WIJAYA, A. L. PENGARUH LIKUIDITAS, PROFITABILITAS, .....

Tabel 7. Hasil Uji Normalitas

\begin{tabular}{|l|l|r|}
\hline \multicolumn{2}{|c|}{ Model } & $\begin{array}{c}\text { Unstandardized } \\
\text { Residual }\end{array}$ \\
\hline $\mathrm{N}$ & & 55 \\
\hline Normal Parameter a & Mean & .0000000 \\
\hline & Std. Deviation & 1.12242754 \\
\hline Most Extreme & Absolut & .131 \\
\hline Differences & Positive & .085 \\
\hline & Negative & .131 \\
\hline Kolmogorov-Smirnov Z & & .975 \\
\hline Asymp. Sig. (2-tailed) & & .298 \\
\hline
\end{tabular}

Lampiran 9

Tabel 8. Hasil Uji Determinasi

\begin{tabular}{|c|r|r|r|r|r|}
\hline Model & $\mathrm{R}$ & R Square & $\begin{array}{c}\text { Adjusted } \\
\text { R Square }\end{array}$ & $\begin{array}{c}\text { Std. Eror of } \\
\text { the Estimate }\end{array}$ & $\begin{array}{c}\text { Durbin- } \\
\text { Watson }\end{array}$ \\
\hline 1 & .432 & .187 & .139 & .1443709510 & 1.616 \\
\hline
\end{tabular}

Lampiran 10

Tabel 9. Uji Simultan (F test)

\begin{tabular}{|l|r|r|r|r|r|}
\hline Model & \multicolumn{1}{|c|}{$\begin{array}{c}\text { Sum of } \\
\text { Squares }\end{array}$} & \multicolumn{1}{c|}{ Df } & $\begin{array}{c}\text { Mean } \\
\text { Square }\end{array}$ & F & Sig. \\
\hline 1. Regression & .244 & 3 & .081 & 3.902 & $.014^{\mathrm{a}}$ \\
\hline Residual & 1.063 & 51 & .021 & & \\
\hline Total & 1.307 & 54 & & & \\
\hline
\end{tabular}

Lampiran 11

Tabel 10. Uji Parsial ( $\mathrm{t}$ test)

\begin{tabular}{|l|r|r|r|r|r|}
\hline \multirow{2}{*}{ Model } & \multicolumn{2}{|c|}{$\begin{array}{c}\text { Unstandardized } \\
\text { Coefficients }\end{array}$} & $\begin{array}{c}\text { Standardized } \\
\text { Coefficients }\end{array}$ & \multirow{2}{*}{ T } & \multirow{2}{*}{ Sig. } \\
\cline { 2 - 5 } & \multicolumn{1}{|c|}{ B } & Std. Error & \multicolumn{1}{c|}{ Beta } & & \\
\hline 2. (constant) & .071 & .048 & & 1.487 & .143 \\
\hline CR & -.015 & .007 & -.302 & -.2076 & .043 \\
\hline ROE & .471 & .196 & .327 & 2.400 & .020 \\
\hline DER & -.047 & .047 & -.151 & -.995 & .324 \\
\hline
\end{tabular}

